\title{
Petrogenesis of Group II kimberlites: a case study from southern
}

\author{
Africa \\ Anton le Roex ${ }^{1}$, Nancy Coe ${ }^{1}$, John Gurney ${ }^{1}$, D. Graham Pearson ${ }^{2}$ and Geoff Nowell ${ }^{2}$ \\ ${ }^{1}$ Department of Geological Sciences, University of Cape Town, South Arica \\ ${ }^{2}$ Department of Earth Sciences, University of Durham, UK
}

The Swartruggens and Star kimberlite dyke swarms are located on the Kaapvaal craton (Fig. 1), South Africa, each consisting of a series of east-west trending en echelon dykes. The Swartruggens kimberlite, located towards the centre of the craton, approximately $60 \mathrm{~km}$ west of the town Rustenberg, has been dated at $156 \mathrm{Ma}$ (Smith et al. 1985). The Star kimberlite is located some 250 further south, $10 \mathrm{~km}$ north of the town of Theunissen, and has an age of approximately $124 \mathrm{Ma}$ (McIntyre and Dawson 1976).

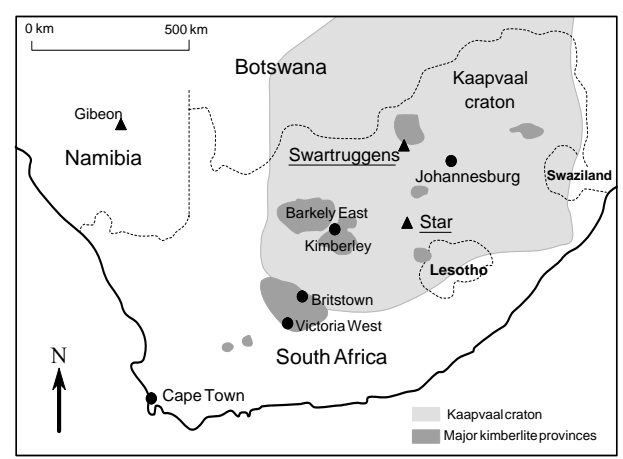

Fig. 1 Map of southern Africa illustrating the location of the Swartruggens and Star kimberlite dyke swarms, the extent of the Kaapvaal craton, and other major kimberlite provinces

Petrographically, the Swartruggens and Star

kimberlites are similar; both contain dominant anhedral to rounded or fractured olivine macrocrysts (up to 10 $\mathrm{mm}$; altered to serpentine along fractures or pervasively, sometimes altered to calcite) and subordinate, highly strained and kink-banded, phlogopite macrocrysts (sometimes altered to chlorite; fractures infilled with calcite), set in a fine-grained phlogopite-rich groundmass. Olivine macrocrysts vary widely in abundance (Swartruggens - 5 to 45 vol. \%; Star - 15 and 35 vol. \%). Phlogopite macrocrysts constitute $<15$ vol. $\%$ and many have thin rims of tetraferriphlogopite.

The Swartruggens and Star Group II diamondiferous kimberlite dyke swarms show geochemical characteristics that allow constraints to be placed on their low pressure evolution and on the composition, evolution and likely location of their mantle source regions. Intra-dyke variations at both localities can be attributed to a combination of variable peridotite entrainment (20-40\%), limited ( 10\%) crystal fractionation (olivine plus phlogopite), superimposed on crustal contamination and groundwater and deuteric alteration. Once these affects have been taken into account, the magmas giving rise to the Swartruggens kimberlite dykes appear to be related to a single parental primary magma, or magmas derived by similar low $(<2 \%)$ degrees of partial 
melting of a homogeneous source composition. In contrast, the Star kimberlite dykes were derived by variable degrees $(0.8-2.2 \%)$ of partial melting of a homogeneous mantle source that is geochemically distinct from that giving rise to the spatially associated, non-diamondiferous, Barren Dyke.

The close-to-primary Swartruggens kimberlite magma contains $\sim 38.1 \mathrm{wt} \% \mathrm{SiO}_{2}, \sim 21.1 \mathrm{wt} \% \mathrm{MgO}$, $\sim 8.54 \mathrm{wt} \% \mathrm{CaO}$ and $\sim 6.64 \mathrm{wt} \% \mathrm{~K}_{2} \mathrm{O}$. For a similar $\mathrm{MgO}$ content $(\sim 21.8 \mathrm{wt} \%)$, the Star close-to-primary kimberlite magma is slightly less enriched in $\mathrm{SiO}_{2}$ $(\sim 36.2 \mathrm{wt} \%)$ and $\mathrm{K}_{2} \mathrm{O}(3.32 \mathrm{wt} \%)$ and more enriched in $\mathrm{CaO}(\sim 10.5 \mathrm{wt} \%)$ than the Swartruggens kimberlite. The close-to-primary magmas at both localities were strongly enriched in incompatible trace elements, with superimposed relative depletion in $\mathrm{K}, \mathrm{Nb}-\mathrm{Ta}$, $\mathrm{Ti}$ and $\mathrm{Sr}$, and strong relative enrichment in $\mathrm{Pb}$, when normalised to primitive mantle values. Both have steep chondrite normalised REE patterns (Swartruggens $\mathrm{La} / \mathrm{Yb}_{\mathrm{n}}=7.4$; Star La/Yb $\left.\mathrm{b}_{\mathrm{n}}=11.0\right)$. Both Swartruggens and Star kimberlites are distinguished from Group I kimberlites by their high $\mathrm{Ba} / \mathrm{Nb}(>12), \mathrm{Th} / \mathrm{Nb}(>1.1)$ and $\mathrm{La} / \mathrm{Nb}(>1.1)$ but lower $\mathrm{Ce} / \mathrm{Pb}(<20)$ ratios $($ Becker and le Roex, 2006).

With respect to their isotope geochemistry, the close-to-primary kimberlite magmas at Swartruggens and Star are slightly different. The Swartruggens closeto-primary magma has ${ }^{87} \mathrm{Sr} /{ }^{86} \mathrm{Sr} \sim 0.70771, \varepsilon \mathrm{Nd}_{\mathrm{i}} \sim-$ 11.37 and $\varepsilon \mathrm{Hf}_{\mathrm{i}} \sim-15.74$, whereas the Star kimberlite had slightly less radiogenic ratios, with ${ }^{87} \mathrm{Sr} /{ }^{86} \mathrm{Sri} \sim$ $0.70748, \varepsilon \mathrm{Nd}_{\mathrm{i}} \sim-8.49, \varepsilon \mathrm{Hf}_{\mathrm{i}} \sim-7.50$. The age difference of approximately $30 \mathrm{Ma}$ between these two kimberlites is not sufficient to account for the difference in their initial isotopic ratios. In terms of $\mathrm{Nd}-\mathrm{Hf}$ isotope characteristics, the Star and Swartruggens Group II kimberlites have thus derived from two compositionally distinct source regions, both of which have experienced similar styles of enrichment - i.e. long-term, time integrated, low $\mathrm{Sm} / \mathrm{Nd}$ and low $\mathrm{Lu} / \mathrm{Hf}$. This contrasts with most lithospheric peridotites that have been measured (e.g., Simon et al. 2007), but is similar to more enriched pyroxenite compositions, consistent with a source metasomatically enriched in clinopyroxene and phlogopite at the expense of garnet.

Quantitative forward modeling of REE patterns indicate derivation of these and other Group II kimberlites from a more highly metasomatised source, by variable degrees of partial melting ( 0.5 to $2 \%$ ), having more residual clinopyroxene and less residual garnet compared to that giving rise to Group I kimberlites (Becker and le Roex, 2006). Model ages for enrichment of the Group II kimberlite source region suggest an ancient (600-1100 Ma) enrichment event. The source regions giving rise to these (and other) Group II kimberlites are characterised by strong enrichment in incompatible elements, relative depletion in $\mathrm{Nb}$, $\mathrm{Ta}$ and $\mathrm{Ti}$, relative enrichment in $\mathrm{Pb}$, and have radiogenic $\mathrm{Sr}$ and unradiogenic $\mathrm{Nd}$ and $\mathrm{Hf}$ compositions (Coe et al., 2008). The isotopic data require long term isolation from the convecting mantle, and consequently the source is considered to be located within the continental lithospheric mantle. The high $\mathrm{Mg} \#$ and $\mathrm{Ni}$ contents of the primary magmas and their calculated source regions are consistent with derivation from refractory continental lithospheric mantle. The relative depletion in $\mathrm{Nb}$, Ta and $\mathrm{Ti}$ and enrichment in $\mathrm{Pb}$ in these (and other) Group II kimberlites is argued to be a consequence of metasomatic enrichment of their mantle source region by calc-alkaline fluids/melt derived during late Proterozoic subduction along the west and southwest margin of Gondwanaland (e.g. Namaqua-Natal event). Later heating or uplift of this metasomatised lithosphere by the rising Shona and/or Bouvet mantle plumes, currently located beneath the South Atlantic, during Gondwana breakup led to low (0.5-2\%) degrees of SCLM melting and Group II kimberlite magmatism.

References

Becker, M., le Roex, A.P., 2006. Geochemistry of South African on- and off-craton, Group I and Group II kimberlites: petrogenesis and source region evolution. Journal of Petrology 47, 673-703. 
McIntyre, R.M., Dawson ,J.B., 1976. Age and significance of some South African kimberlites. Abstracts of the 4th

European Colloquim of Geochronology, Cosmochronology and Isotope Geology, Amsterdam, Abstract 66.

Smith, C.B., Allsopp, H.L., Kramers, J.D., Hutchinson, G., Roddick, J.C., 1985. Emplacement ages of Jurassic-

Cretaceous South African kimberlites by the Rb-Sr method on phlogopite and whole-rock samples. Transactions of the Geological Society of South Africa 88, 249-266.

Simon N.S.C. Carlson R.W., Pearson D.G. and Davies G.R., (2007). The origin and evolution of the Kaapvaal cratonic lithospheric mantle. J. Petrology, 48, 589-625.

Coe N, le Roex AP, Gurney JJ, Pearson G and Nowell G (2008) Petrogenesis of the Swartruggens and Star Group II kimberlite dyke swarms, South Africa: constraints from whole rock geochemistry. Contib. Mineral. Petrol.

10.1007/s00410-008-0305-1 